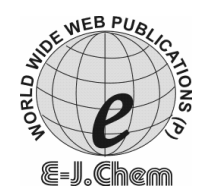

http://www.e-journals.net

ISSN: 0973-4945; CODEN ECJHAO

E-Journal of Chemistry

2008, 5(S2), 1159-1164

\title{
Solubility and Dissolution Rate Determination of Different Antiretroviral Drugs in Different pH Media Using UV Visible Spectrophotometer
}

\author{
K. PRAKASH ${ }^{\S *}$ P. NARAYANA RAJU ${ }^{\#}$, \\ K. SHANTA KUMARI ${ }^{\S}$ and M. LAKSHMI NARASU \\ ${ }^{\S}$ SN Vanitha Mahavidyalaya Pharmacy College for Women, \\ Nampally, Hyderabad, Andhra Pradesh, India. \\ ${ }^{\text {\#} S t ~ P e t e r ' s ~ I n s t i t u t e ~ o f ~ P h a r m a c e u t i c a l ~ s c i e n c e s, ~}$ \\ Hanmakond, Warangal. Andhra Pradesh, India. \\ Centre For Biotechnology, \\ Institute of Science and Technology, JNTU, \\ Kukatpally, Hyderabad, Andhra Pradesh, India. \\ nrpadala@rediffmail.com
}

Received 18 December 2007; Revised 10 March 2008; Accepted 5 June 2008

\begin{abstract}
Solubility and dissolution rate of three antiretroviral drugs such as lamivudine, zidovudine and stavudine was studied in four media having different $\mathrm{pH}$. The samples were analyzed by using UV Visible spectrophotometer. lamivudine shows more solubility that is $276.08 \mathrm{mg} / \mathrm{mL}$ in $0.01 \mathrm{~N} \mathrm{HCl}$. Stavudine showing highest solubility that is $101.23 \mathrm{mg} / \mathrm{mL}$ in $\mathrm{pH} 4.5$ acetate buffer. Zidovudine showing highest solubility that is $28.90 \mathrm{mg} / \mathrm{mL}$ in both water and $0.01 \mathrm{~N}$ $\mathrm{HCl}$. All three drugs showing lower solubility in $\mathrm{pH} 6.8$ phosphate buffer. Lamivudine and stavudine showing good dissolution rate in all media and showing similar release profiles and good correlation, whereas in zidovudine it was clearly observed a slower release at initial time points and then faster release profiles. The solubility and dissolution data in various media is helpful in predicting the bioavailability and also in dissolution method development.
\end{abstract}

Keywords: Solubility, GIT, Dissolution, Antiretroviral drugs.

\section{Introduction}

The oral bioavailability of a drug is a highly complicated property. It is mainly depends on the drug's solubility in the gastrointestinal tract and its absorption into the blood stream ${ }^{1,2}$. Aqueous solubility of a chemical is defined as the amount of solute dissolved in a saturated 
aqueous solution under equilibrium conditions. Solubility is not only a property of interest to many areas of academic research, but also a key parameter when it comes to drug design and formulation development in the pharmaceutical industry ${ }^{3}$. The solubility of active ingredient(s) is one of the key aspects in screening of possible dissolution media ${ }^{4}$ for the oral dosage forms. The dissolution of formulations in different media is a regulatory requirement ${ }^{5}$ and is directly useful in predicting the drug absorption throughout the gastro intestinal tract. However, the solubility of drug molecules varies considerably with the $\mathrm{pH}$, and as the $\mathrm{pH}$ takes different values throughout the gastrointestinal tract. $\mathrm{pH}$-dependent solubility would significantly assists in improving the modeling of oral bioavailability of drugs. In pre-formulation drug solubility in different $\mathrm{pH}$ media is important aspect because it directly simulate the drug absorption through out the GI tract ${ }^{6-8}$. Hence solubility and dissolution rate are interrelated because the dissolution rate is mainly depends on the drug solubility in the dissolution medium. In the present research work we have studied the solubility and dissolution rate of three anti retroviral drugs such as lamivudine, zidovudine and stavudine. These dugs are official in the United States Pharmacopoeia (USP) ${ }^{9}$.

\section{Experimental}

\section{Instruments}

All the absorbance values were measured on UV- visible spectrophotometer Schimadzu, UV-1700 E 23. Mechanical shaker, ORBITEX, Scigenics biotech was used for shaking of volumetric flasks. The in vitro dissolution studies were performed using USP type I dissolution apparatus LABINDIA, DISSO-2000, Mumbai, India.

\section{Materials}

Lamivudine, zidovudine, and stavudine were obtained as a gift sample from Alkem laboratories Ltd (Mumbai, India). The tablets for dissolution rate determination were purchased form commercial market. All other chemicals and reagents used in the study were of analytical grade.

\section{Construction of standard calibration curves for lamivudine, zidovudine and stavudine}

Accurately weighed quantity of lamivudine was transferred in to the volumetric flask. Required quantity of water was added to the above volumetric flask. Shake the volumetric flask until the complete solubility of the drug and make up the volume with remaining quantity of water. This is stock solution for the construction of lamivudine standard calibration curve. Similarly stock solutions for lamivudine were prepared in the following media such as $0.01 \mathrm{~N}$ HCL, USP acetate buffer $\mathrm{pH} 4.5$ and USP phosphate buffer $\mathrm{pH} 6.8$. Standard calibration curves for lamivudine were constructed using above stock solutions. Similarly above mention procedure was applied to zidovudine and stavudine for the construction of standard calibration curves.

\section{Determination of solubility for lamivudine zidovudine and stavudine in various $p H$ media}

Required quantity of water was transferred in to volumetric flask. The water was heated up to $37 \pm 0.5^{\circ} \mathrm{C}$ using magnetic stirrer provided with heat. Previously weighed quantity of lamivudine was added to the above volumetric flask until the saturation point occurs. The total quantity of lamivudine added was recorded. Stirring was continued up to 5 hours at $37 \pm 0.5^{\circ} \mathrm{C}$. The sample was filtered through $0.45 \mu \mathrm{m}$ membrane filter (MILLIPORE). A measured 
quantity of filtered sample was transferred in to another volumetric flask and made further dilutions. The absorbance was measured using UV visible spectrophometer. Repeat the same process mentioned above using $0.01 \mathrm{~N}$ HCL, USP acetate buffer $\mathrm{pH} 4.5$ and USP phosphate buffer $\mathrm{pH}$ 6.8. Similarly the above process was applied to zidovudine and stavudine for the determination of solubility. The results were graphically represented in Figure 1. The solubility in different media was summarized in Table 1.

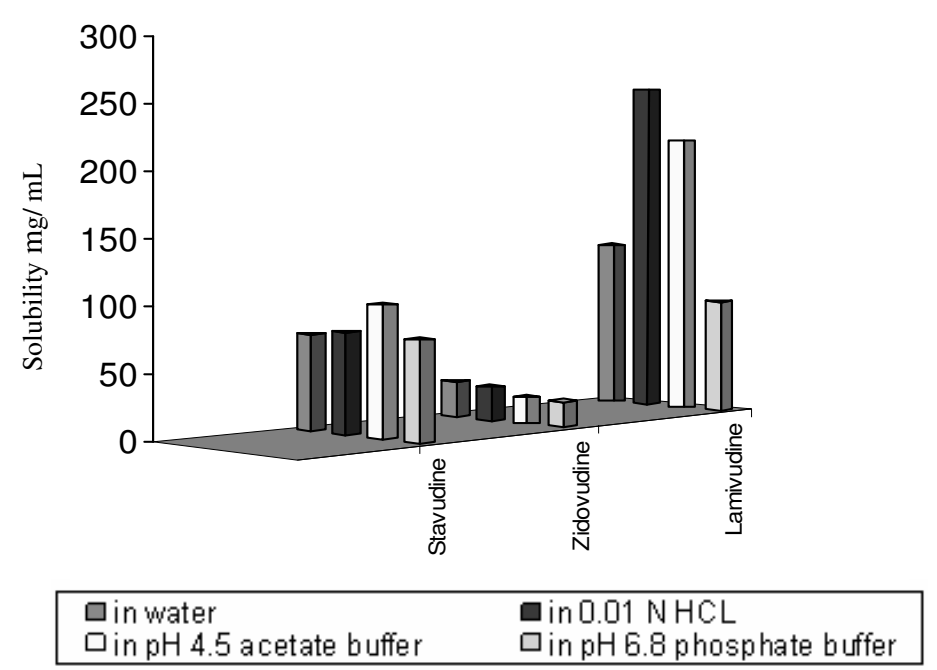

Figure 1. Solubility data of lamivudine, zidovudine and stavudine in various $\mathrm{pH}$ media

Table 1. Solubility of lamivudine, zidovudine and stavudine in various $\mathrm{pH}$ media

\begin{tabular}{lcccc}
\hline & Water & $\begin{array}{c}0.01 \mathrm{~N} \\
\mathrm{HCl}\end{array}$ & $\begin{array}{c}\mathrm{pH} 4.5 \text { Acetate } \\
\text { buffer }\end{array}$ & $\begin{array}{c}\mathrm{pH} 6.8 \text { phosphate } \\
\text { buffer }\end{array}$ \\
\hline LAMI, $\mathrm{mg} / \mathrm{mL}$ & 140.01 & 276.08 & 230.50 & 92.76 \\
ZIDO, $\mathrm{mg} / \mathrm{mL}$ & 28.90 & 27.36 & 21.36 & 20.10 \\
STAV $\mathrm{mg} / \mathrm{mL}$ & 75.36 & 78.19 & 101.23 & 76.13 \\
\hline
\end{tabular}

Key: LAMI-Lamivudine, ZIDO-Zidovudine, STAV-Stavudine.

Determination of dissolution rate for lamivudine zidovudine and stavudine in various $\mathrm{pH}$ media

The drug release rate form stavudine capsules was characterized using USP type 1 at 75 $\mathrm{rpm}, 900 \mathrm{~mL}$ of dissolution medium at $37 \pm 0.5^{\circ} \mathrm{C}$. The dissolution media used in the study were water, $0.01 \mathrm{~N} \mathrm{HCL}$, USP acetate buffer $\mathrm{pH} 4.5$ and USP phosphate buffer $\mathrm{pH}$ 6.8. A sample of $5 \mathrm{~mL}$ of sample was withdrawn form the dissolution medium and replaced with 5 $\mathrm{mL}$ of blank media. The samples were withdrawn at 5, 10, 15, 30 and 45 minutes and analyzed using UV visible spectrophometer. The results of dissolution rate were summarized in Table 2 and Figure 4.

The drug release rate form lamivudine and zidovudine form tablets were characterized using USP type 2 at $50 \mathrm{rpm}, 900 \mathrm{~mL}$ of dissolution medium at $37 \pm 0.5^{\circ} \mathrm{C}$. The various dissolution media used in the study were water, $0.01 \mathrm{~N} \mathrm{HCL}$, USP acetate buffer $\mathrm{pH} 4.5$ and USP phosphate buffer $\mathrm{pH}$ 6.8. A sample of $5 \mathrm{~mL}$ of sample was withdrawn form the dissolution medium and replaced with $5 \mathrm{~mL}$ of blank media. The samples were withdrawn at 
5, 10, 15, 30 and 45 minutes and analyzed using UV visible spectrophometer. The results of dissolution rate were summarized in the Table 2, Figures 2 and 3.

Table 2. In-vitro dissolution rate of lamivudine tablets $150 \mathrm{mg}$, zidovudine tablets $300 \mathrm{mg}$ and stavudine capsules $30 \mathrm{mg}$ in various $\mathrm{pH}$ media

\begin{tabular}{|c|c|c|c|c|c|c|c|c|c|c|c|c|}
\hline & \multicolumn{3}{|c|}{ Water } & \multicolumn{3}{|c|}{$0.01 \mathrm{~N} \mathrm{HCl}$} & \multicolumn{3}{|c|}{$\begin{array}{c}\mathrm{pH} 4.5 \text { Acetate } \\
\text { buffer }\end{array}$} & \multicolumn{3}{|c|}{$\begin{array}{c}\mathrm{pH} 6.8 \text { phosphate } \\
\text { buffer }\end{array}$} \\
\hline \multirow[t]{2}{*}{$\begin{array}{r}\text { Time } \\
\text { min }\end{array}$} & \multicolumn{12}{|c|}{ Cumulative $\%$ released } \\
\hline & LAM & ZIDO & TAV & LAMI & ZIDO & STAV & LAMI & ZIDC & STAV & LAM & ZIDO & STAV \\
\hline 5 & 95 & 76 & 86 & 91 & 53 & 88 & 94 & 55 & 92 & 89 & 62 & 87 \\
\hline 10 & 95 & 88 & 92 & 93 & 88 & 99 & 95 & 73 & 99 & 92 & 76 & 96 \\
\hline 15 & 96 & 92 & 100 & 93 & 93 & 100 & 95 & 86 & 100 & 96 & 88 & 100 \\
\hline 30 & 96 & 96 & 100 & 95 & 95 & 100 & 96 & 91 & 100 & 99 & 91 & 100 \\
\hline 45 & 97 & 99 & 100 & 96 & 99 & 100 & 99 & 97 & 100 & 99 & 96 & 100 \\
\hline
\end{tabular}

Key: LAMI-Lamivudine tablets $150 \mathrm{mg}$ tablets, ZIDO-Zidovudine $300 \mathrm{mg}$ tablets, STAV-Stavudine 30 mg capsules.

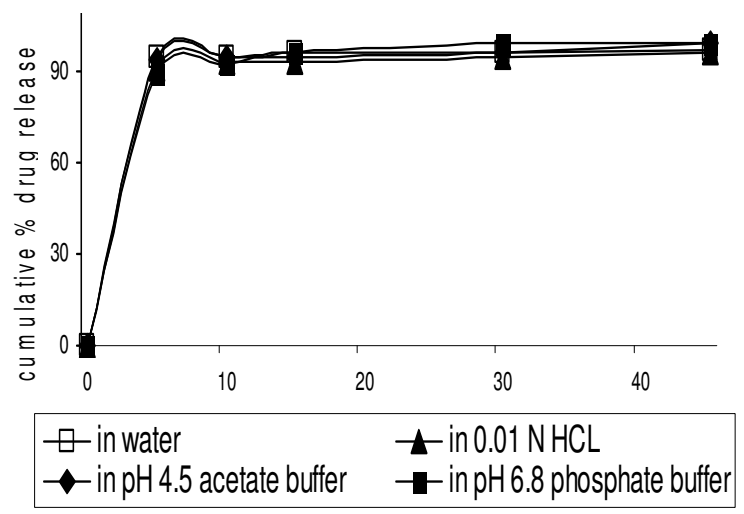

Figure 2. Drug release rate of Lamivudine tablets $150 \mathrm{mg}$ in various $\mathrm{pH}$ media

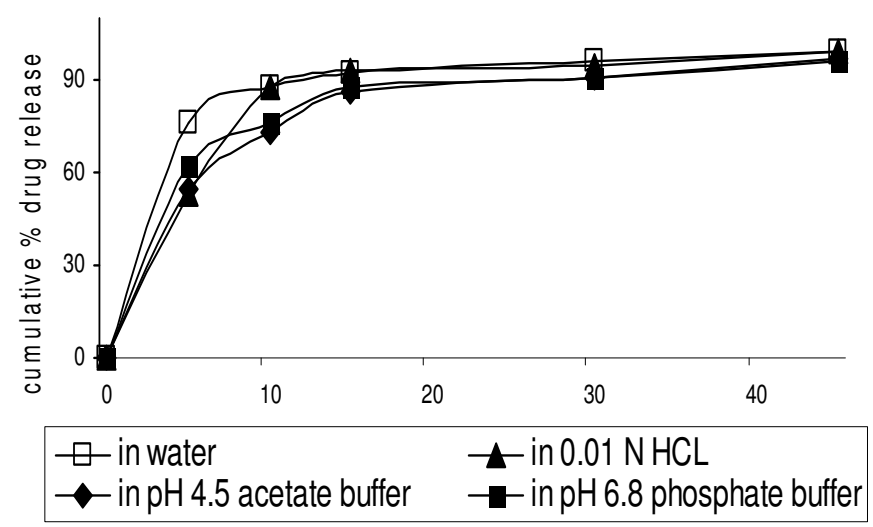

Figure 3. Drug release rate of Zidovudine tablets $300 \mathrm{mg}$ in various $\mathrm{pH}$ media 


\section{Results and Discussion}

All three drugs lamivudine, zidovudine and stvudine showing good solubility profile in all $\mathrm{pH}$ media. Lamivudine shows highest solubility in $0.01 \mathrm{~N} \mathrm{HCl}$ where as stavudine showing highest solubility in $\mathrm{pH} 4.5$ acetate buffer. Zidovudine showing highest solubility in both water and $0.01 \mathrm{~N} \mathrm{HCl}$. All three drugs showing lowest solubility in $\mathrm{pH} 6.8$ phosphate buffer, however it is negligible when compared with the dosage wise solubility as defined in bio pharmaceutical system (BCS) of solubility classification. Figure 1 is the graphical representation of solubility data of all the drugs.

The dissolution of lamivudine and stavudine in all $\mathrm{pH}$ media showing similar release profile and showing good correlation (Figure 2 and Figure 4), whereas in case of zidovudine it was clearly observed a slower release at initial time points (Figure 3) and then showing faster release profiles. The overall dissolution rate of all these three drugs showing more than $86 \%$ of drug release form their dosage forms is clearly indicating the availability of drug at the site of absorption.

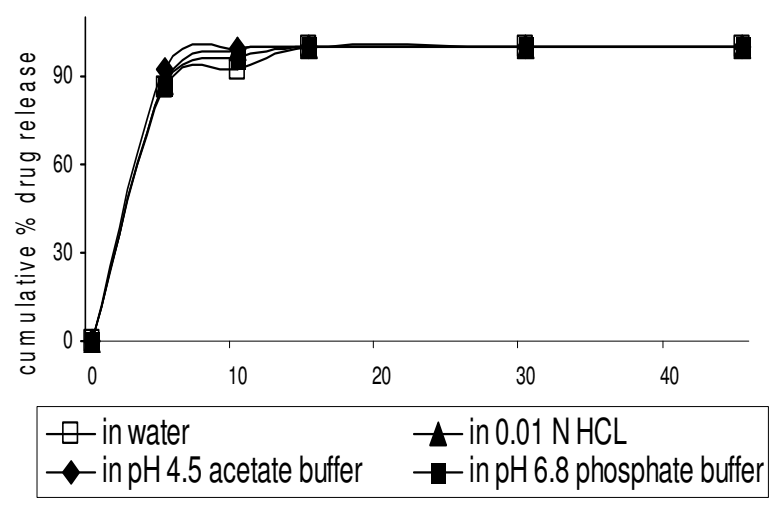

Figure 4. Drug release rate of stavudine capsules $30 \mathrm{mg}$ in various $\mathrm{pH}$ media

\section{Conclusion}

Solubility determination in various $\mathrm{pH}$ media is a prerequisite in drug development because it gives the complete idea of drug behavior in various $\mathrm{pH}$ media. With the solubility data we can predict the drug absorption. Based on the solubility data we can develop a good dissolution medium which is essential for absorbable drugs. Based on the above solubility data we can conclude that all the drugs are high soluble. The dissolution data in various $\mathrm{pH}$ media is helpful in predicting the bioavailability and also in dissolution method development when we prepare a combination of drug product.

\section{References}

1. Ansal H C, Popovich N G and Allen L V Jr. Pharmaceutical dosage forms and drug delivery systems, B.I Waverly, $6^{\text {th }}$ Ed, New Delhi, 1999, 61.

2. Cuny L D, Huwyler J, Wiese M and Kansy M, Eur J Med Chem.,2008, 43, 501.

3. Lipinski C A, Lombardo F, Dominy B W and Feeney P J, Adv Drug Delivery Reviews, 2001, 46, 3.

4. Gray V A, Brown C K, Dressman J B and Lesson J, New General Information on Dissolution. Pharmacopeial Forum 2001, 27, 3432. 


\section{K PRAKASH et al.}

5. Guidance for Industry, Dissolution Testing of Immediate Release Solid Oral Dosage Forms. Center for Drug Evaluation and Research, www.fda.gov, 1997

6. Guidance for Industry, Dissolution testing of immediate release solid oral dosage forms. Extended release oral dosage forms, Center for drug evaluation and research (CDER), www.fda.gov, 1997.

7. Moore J and Flanner H, Pharm.Tech. 1996, 20- 64.

8. Shah. P, Tsong L, Sathe P and Williams R L, Dissolution Technol. 1999, 6, 21.

9. The United States Pharmacopoeia, The official compendia of standards, $29^{\text {th }}$ Ed, 2003, 1225. 


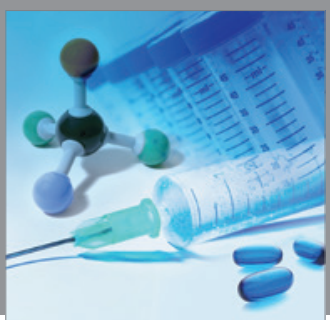

International Journal of

Medicinal Chemistry

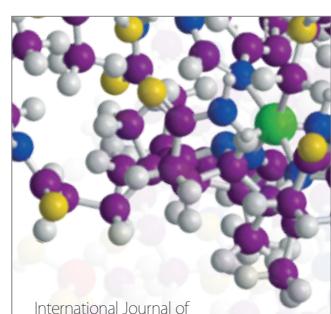

Carbohydrate Chemistry

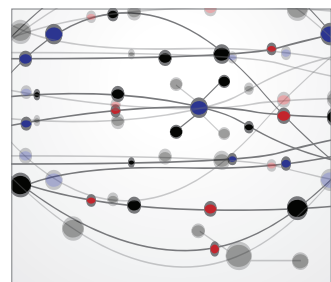

The Scientific World Journal
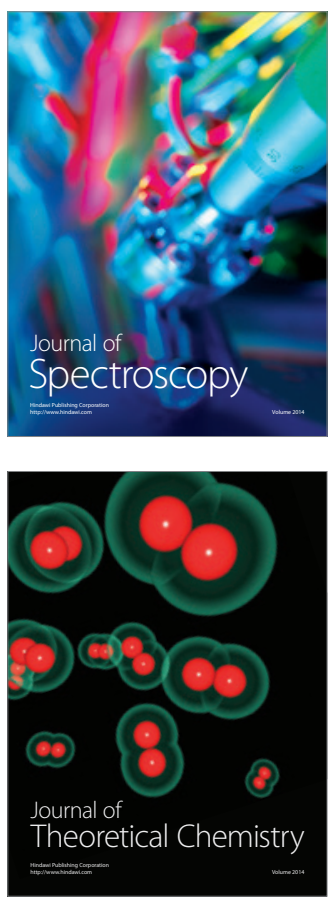
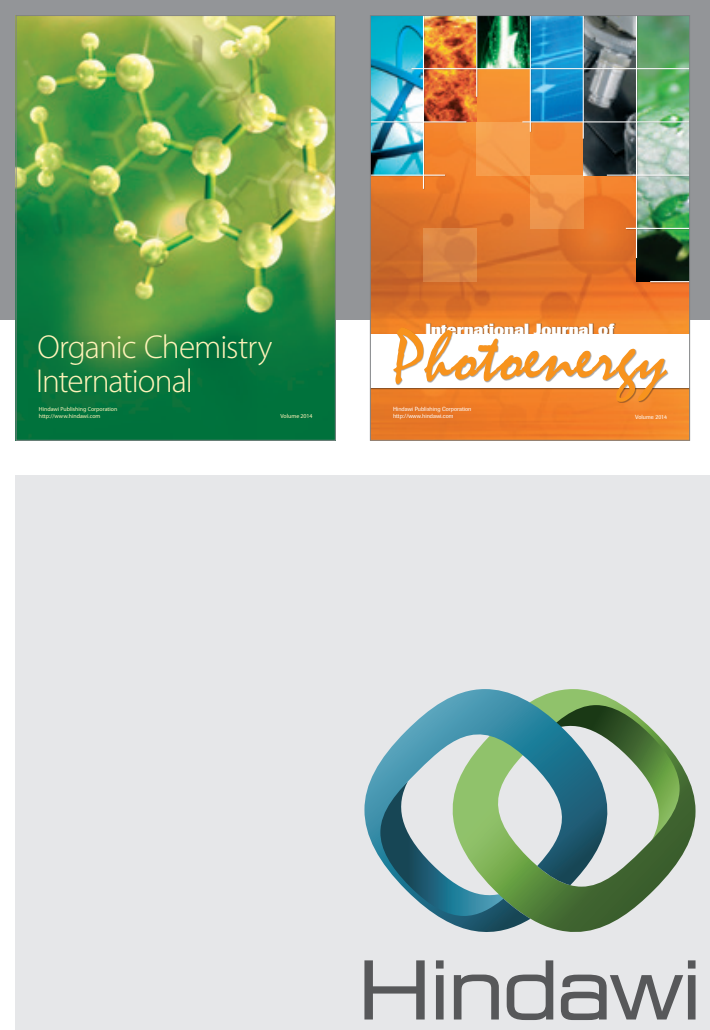

Submit your manuscripts at

http://www.hindawi.com
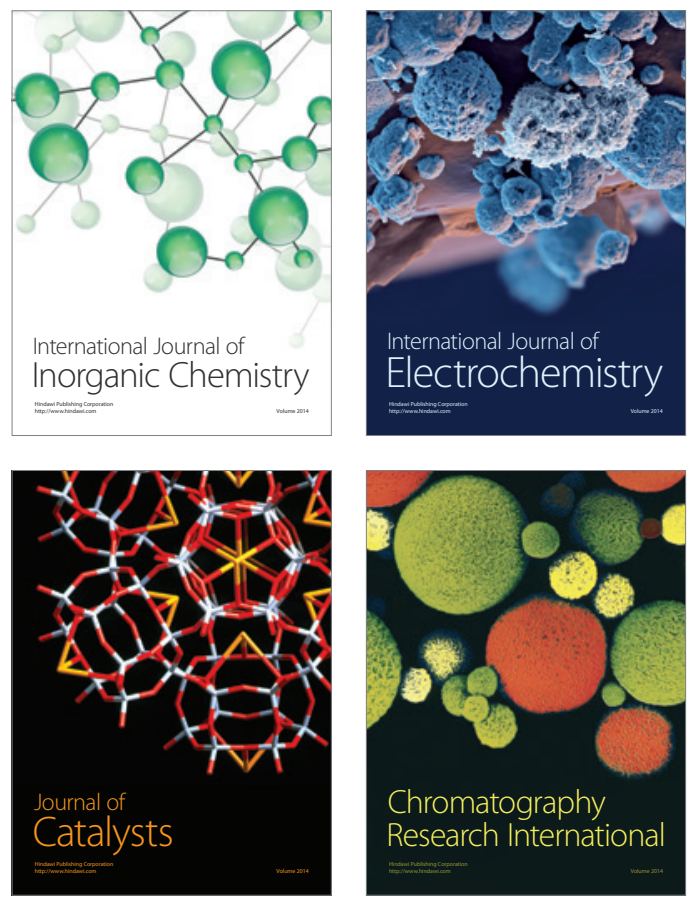
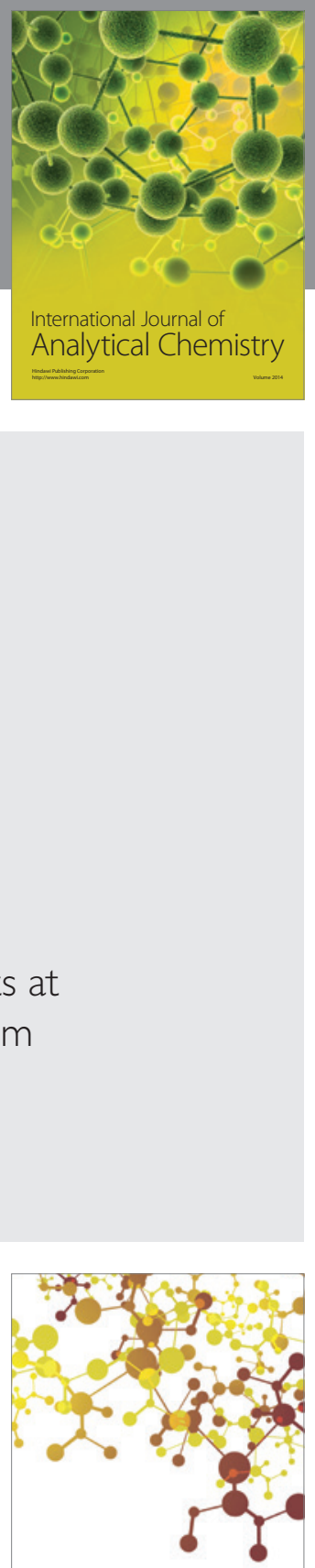

Journal of

Applied Chemistry
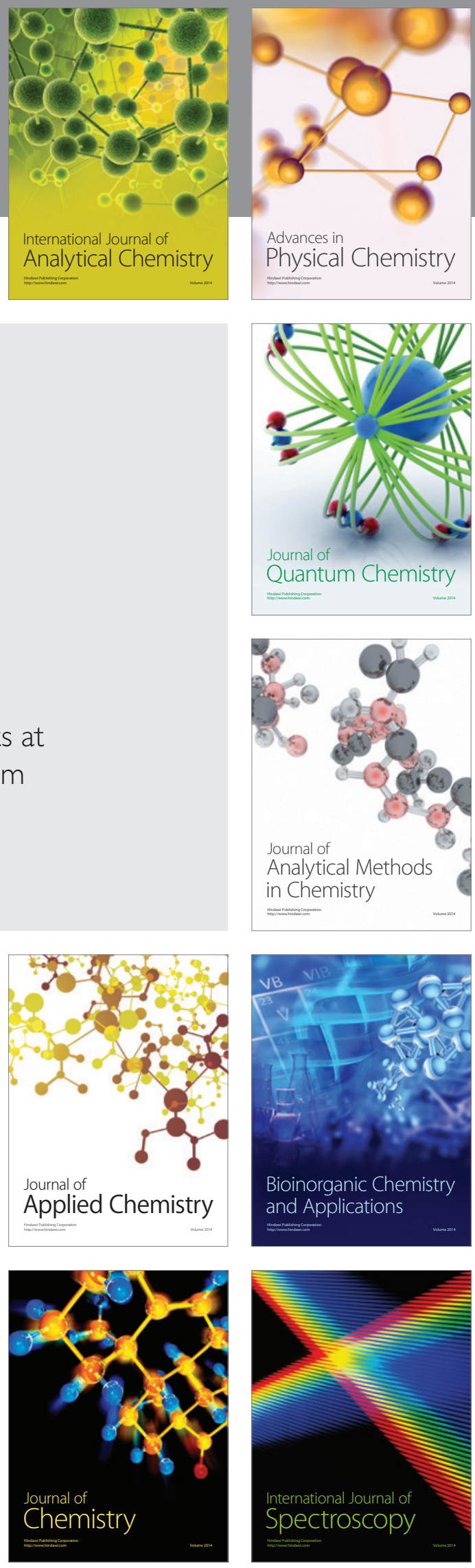